\title{
JUURNAL.RU
}

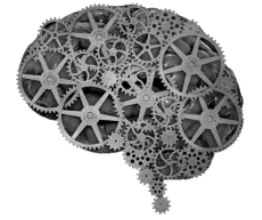

COMPANY GROUP "INTELLEKT"

\author{
Гаджиева А.М. ${ }^{1}$ Ахундова С.Л. ${ }^{2}$ \\ ${ }^{1}$ Азербайджанский государственный педагогический университет \\ ${ }^{2}$ Бакинский Славянский Университет \\ Азербайджан
}

doi: 10.18411/lj2016-5-1-03

\section{Формирование культуры здорового образа жизни средствами учебных дисциплин}

В современный период нарушение экологического равновесия стало причиной возникновения изменений в живой и неживой природе, кризисов в различных областях. Проблема питьевой воды, изобилие трансгенных фруктов и овощей, низкокачественные продукты питания, нарастание стихийных бедствий в природе оказывают негативное влияние на здоровье человека.Все это создает условия длявсе большего увеличения и быстрого распространения трудноизлечимых болезней.

В настоящее время во многих странах люди сталкиваются с проблемами питьевой воды, белкового голодания, демографических вспышек и другими глобальными проблемами. Изменение окружающей среды, употребление непригодных продуктов питания, стало причиной распространения инфекционных и инвазивных болезней между людьми и животными, увеличения новых, доселе неизвестных науке, страшных и трагических болезней, которые требуют длительного лечения (СПИД, птичий грипп, атипичная пневмония, желтая лихорадка, коровье бешенство, гепатит и т.д.), наследственных заболеваний у детей (талассемия, гемофилия, анемия, иммунодефициты),поставив тем самым человечество перед лицом новых угроз.

Различные процессы, происходящие в мире, такие как стихийные бедствия, войны, терроризм, эпидемии, оккупационная политика некоторых 
стран, ставят перед человечеством вопрос здоровья как глобальную проблему.Несмотря на осуществление мер по решению проблем глобального и регионального масштаба, создание новых законов и указов до сих пор не обеспечили полное здоровье людей. Поэтому, чтобы научитьмолодых людей вести здоровый образ жизни, необходимо расширять их медико-гигиенических знания, не нарушая других принципов (3).

В Законах и распоряжениях, направленных на развитие образования, в частности, в принятой в октябре 2013 года "Национальной стратегии развития образования в Азербайджанской Республике» человеческий фактор и его здоровье преподносится как насущная проблема. Указывается, что здоровье квалифицированного, опытного, всесторонне развитого гражданина является основным требованием современного периода.

Перед медицинскими и педагогическими кадрам в качестве основной цели ставится задача формирования у молодого поколения культуры питания, экологических, медицинских знаний и умений, которые являются главным условием здорового образа жизни. Обосновывается тот факт, что сообщаемые медицинские знания и прививаемые навыки должны соответствовать их возрасту, уровню образования и образу жизни.

В процессе преподавания в средней школе таких предметов, как «Познание мира» и «Биология» имеется возможность давать школьникам обширные знания в области биологии, экологии, медицины, гигиены. Так, например, в курсе «Познание мира» при изучении темы «Здоровье и безопасность» целесообразно не только пропагандировать здоровый образ жизни, но и акцентировать внимание учащихся на факторах, угрожающих здоровью человека и мерах защиты от них.

Как правило, такие темы изучаются во взаимосвязи с понятиями о бытовых условиях жизни учащихся, основными факторами здорового образа жизни. Преподавание в школьном курсе биологии раздела «Человек и его здоровье» основывается на изучении секретов здорового образа жизни. 
Школьники изучают строение организма человека, функции различных его органов. Нарушения в строении и функциях организма объясняются как патологический процесс, а также указываются пути их своевременного устранения. Изучение структуры и функций каждого органа проводится в соответствии с заболеваниями, которые могут возникнуть, помимо этого школьникам прививают культуру здорового образа жизни.

В преподавании предмета «Познания мира» и «Биологии» школьников можно обучить 10 золотым правилам, связанных со здоровьем. Учитель последовательно объясняет и обобщает их следующим образом:

1. Рекомендуется употреблять разнообразную пищу. Ежедневное употребление одной и той же еды снижает ее вкусовое восприятие. Использование разнообразных фруктов и овощей, мяса и мясопродуктов, молока и молочных продуктов способствуют укреплению здоровья и оптимистичному жизненному настрою. Ежедневный рацион питания должен включать сезонные свежие фрукты и овощи, следует отдавать предпочтение натуральным экологически чистым продуктам. Кроме того, надо избегать чрезмерно частого употребления продукции, созданной в искусственных условиях, стараться уменьшить использование консервированных продуктов, т.к.витамины и минералы содержатся в них в незначительном количестве.

2. Количество употребляемых продуктов питания измеряется в калориях. Когда человек потребляет больше пищи, чем это необходимо, то она собирается в организме в виде жировых отложений, и начинается процесс ожирения. Количество пищи, должно соответствовать образу жизни человека. Те, кто ведут активный образ жизни и больше находятся в движении, должны использовать продукты с большим количеством калорий, а ведущим сидячий образ жизни желательно употреблять низкокалорийные продукты. 
3. Ежедневное потребление пищи должно быть разделено на соответствующие части. Рекомендуется принимать пищу в течение дня 3-6 раз. Пища должна быть тщательно пережевана.

4. В составе пищи должно быть необходимое количество белка (протеина), соответствующего потребностям организма. Наиболее эффективно, когда в среднем на 1 кг приходится 0,9 \% белка (например, для женщины весом 60 кг необходимо 54 г белка, а для мужчины весом 80 кг примерно 72 г белка). Употребление человеком мясных блюд 2 раза в неделю удовлетворяет потребности организма в белках. Т.к. большое количество белков переходит затем в жиры, то это впоследствии создает условия для ожирения организма.

5. Количество употребляемых жиров также должно контролироваться. Во вторых блюдах процент жиров бывает больше, чем в остальных. Регулярное потребление жареных продуктов, колбасы, различных фаст фудов вредно для организма. Для предотвращения риска ожирения, люди, ведущие преимущественно сидячий образ жизни, должны мало использовать жирные блюда.

6. Ежедневное использование свежих фруктов, овощей и зерновых продуктов удовлетворяет потребности организма в витаминах и минералах, способствует укреплению здоровья.

7. В связи с тем, что сахара в организме достаточно быстро переходят в жиры, потребление их также должно быть нормированным. Поэтому, заботясь о здоровье, человек в своем рационе должен сократить потребление сахарозаменителей, различных кондитерских изделий, которые содержат большое количество углеводов.

8. Качество еды во многом зависит от способов ее приготовления. Блюда, приготовленные при сильной жарке или длительном кипячении, теряют значительное количество витаминов и минералов. При сильном измельчении фруктов или перемалывании зерновых продуктов, 
витамины, содержащиеся в них, также уменьшаются. В результате длительного хранения приготовленной еды также ухудшается ее качество, количество витаминов и минералов снижается.

9. Вода входит в состав потребляемой пищи и является важным компонентом питания. В состав воды входит большое количество минеральных солей. Вода играет важную роль в реакциях, происходящих внутри организма. Она регулирует температуру тела, влияет на процессы пищеварения, способствует удалению вредных веществ из организма. Употребление 2-3 л жидкости в день благоприятно влияет на здоровье человека. Жидкость может быть в виде минеральной воды, натуральных фруктовых и овощных соков. Лимонады, морсы и нектары, приготовленные с использованием концентратов, красителей, консервантов не обладают полезными свойствами и не могут в достаточной степени заменить натуральные соки и минеральную воду.

10. Занятия спортом и активный образ жизни способствуют развитию мышления, интеллекта, регулируют кровообращение, избавляют человека от стресса. Подвижность, физическая активность являются необходимыми требованиями здорового организма. Однако, надо иметь в виду, что чрезмерные физические нагрузки без предварительной подготовки могут навредить организму. Прогулки на свежем воздухе, в лесу, солнечные ванны оказывают благотворное влияние на организм.

Учитель объясняет учащимся каждое правило, используя слайды, затем переходит к гигиене питания. Поясняет, что соблюдение гигиены питания является одним из основных факторов здорового образа жизни. Преподаватель уточняет 5 основных принципов гигиены питания и обобщает их следующим образом (4).

- Соблюдение мер по предохранению пищи от болезнетворных микроорганизмов, распространяющихся посредством людей, животных, насекомых-вредителей; 
- Необходимо правильное отделение сырых продуктов от термически обработанной пищи, для того чтобы предотвратить их от порчи;

- Приготовление пищи при определенной температуре, с целью уничтожения болезнетворных микроорганизмов;

- Хранение продуктов при определенной температуре;

- Тщательное промывание продуктов питания чистой водой.

Учитель также предупреждает учащихся о том, что существуют продукты, которые опасны для здоровья. Он указывает, что в настоящее время широко распространены и особенно популярны среди молодого поколения такие продукты как чипсы, газированные напитки, фаст фуды, колбасы и колбасные изделия, маргарин, различные сладости, приготовленные с использованием маргарина и консервантов, энергетические напитки, жвачки, майонезы, кетчупы, а также молоко и молочные продукты с длительным сроком годности, привезенные из-за рубежа фрукты и овощи. Но все вышеперечисленные продукты небезопасны для организма человека и могут нанести урон его здоровью.

Учащимся объясняется, что в чипсах в высоких дозах содержатся красители и ароматизаторы в смеси с некачественными маслами и углеводами. Кроме того, они содержат канцерогенные вещества. Жиры, содержащиеся в чипсах, повышают уровень холестерина в крови, что повышает риск возникновения инсульта и инфаркта. Частое употребление чипсов может быть причиной ожирения. Энергетическая ценность 200 г чипсов составляет 1100 ккал, что является половиной суточной дозы взрослого человека. Лимонады также располагаются на одной ступени с чипсами. Лимонад представляет собой смесь сахаров, газов и химических веществ. Обычно в лимонад добавляется синтетический сахарозаменитель (аспартам), который по некоторым данным вызывает у людей депрессию, паническое состояние. После того как человек выпил лимонад, ему хочется еще большей дозы этого напитка, в результате 
этого чувство жажды не утоляется, а наоборот, увеличивается. Следует отметить, что в лимонаде в большом количестве содержится сахар (в 0,33 мл банке содержится 6-7 чайных ложек сахара). Регулярное употребление такого большого количества сахара может привести к различным нарушениям в организме человека. Консерванты, красители и другие вредные вещества, содержащиеся в лимонаде, постепенно накапливаются в организме и могут стать причиной различных заболеваний (аллергия, кожные болезни, болезни органов пищеварения и т.д.).

До сведения учащихся доводится тот факт, что энергетические напитки, пользующиеся особой популярностью среди молодежи, содержат в большом количестве кофеин, сахар, красители и другие химические добавки, имеют высокие калории. Все быстро приготовляемые блюда (гамбургер, донер, картошка-фри и др.) и полуфабрикаты (готовые супы, вермишель, пюре и др.) опасны для здоровья. Часто употребляемые такие продукты приводят к различным желудочно-кишечным расстройствам.Содержащийся в этих продуктах фенол обладает высокой токсичностью. Многие эти продукты в качестве сырья содержат ГМО. Такие трансгенные продукты влияют на организм человека на генетическом уровне и могут стать причиной мутаций.

Учитель указывает также, что загрязнение воздуха, увеличение в составе воздуха выхлопных газов, пыли, аэрозолей может привести к заболеваниям органов дыхания. Вредное воздействие солнечных лучей, радиационного излучения в воздухе может стать причиной рака кожи, радиационных ожогов кожи и т.д. Следовательно, для предотвращения этих заболеваний, надо летом защищаться от вредного воздействия солнечных лучей и радиации. Следует воздерживаться от чрезмерно частого пользования мобильными телефонами, компьютером, телевизором, излучающих радиацию, т.к. неправильное их использование также может стать причиной болезней различных органов.

Как известно, в древности рак был очень редкой болезнью и практически не встречался. Канцерогены - это продукты современной цивилизации и 
загрязненной окружающей среды. Поэтому ученые советуют свести к минимуму, насколько это возможно, контакт с цивилизацией. Основная причина распространения рака сегодня, вредные привычки, запущенные болезни, употребление ряда лекарственных препаратов и др. Самым опасным видом рака является рак мозга (1).

Учитель, в частности, доводит до сведения учащихся, что наличие у людей экологического мышления, медицинских знаний и культуры здорового образа жизни является главным условием и играет важную роль в предотвращении этих страшных болезней.

Подводя итоги, учитель объясняет, что человек является частью природы, и должен защищать и охранять ее, сохранять окружающую среду в чистоте. Природа кормит нас своими богатствами, развивает физические и духовные силы, украшает нашу жизнь.Но человек портит природу - источник жизни, нарушает экологический баланс, отравляетвоздух, которым дышит, питьевую воду, почву, плоды которой поедает. Этот путь,создавая страшные бедствия, болезни, ведет к разрушению самого человечества. Люди уже теряют свою ответственность перед природой. Человечество, представив свою трагическую гибель, должно незамедлительно встать на путь развития и культуры здорового образа жизни. Нужно бережно относиться к природе, не портить окружающую среду, вести борьбу за улучшение экологического состояния и равновесия родного края и всего мира.

В преподавании предметов координация тем и текстов с культурой здорового образа жизни должна способствовать здоровому развитию молодого поколения, повышать у них экологическую культуру. Связь обучения с жизнью, повышает его качество, помогает учащимся правильно усвоить материал, осознавать важность здорового образа жизни, приобретать медицинские, экологические знания и умения. 


\section{Литература:}

1. Алиев С.Дж., Гаджиева А.М., МикаилзадеН.Дж. Основы медицинских знаний. Учебник для ВУЗов. Баку, 2013.

2. Гасымов М. За здоровый образ жизни. Баку, 2015.

3. Гаджиева А.М. Система работ по обучению медицинским знаниям в преподавании биологии в средней школе. Монография. Баку, 2007.

4. Интернет-ресурсы. 